\title{
PERFORMANCE EVALUATION OF INTERLOCKING BRICKS USING GRANITE WASTE POWDER
}

\author{
Fatheali A Shilar \\ School of Civil and Environmental Engineering \\ KLE-Technological University, Hubli, \\ Karnataka, India
}

\author{
S.S.Quadri \\ School of Civil and Environmental Engineering \\ KLE-Technological University, Hubli, \\ Karnataka, India
}

\begin{abstract}
This paper mainly focus on utilisation of industrial wastes in making interlocking building brick, Flyash and Granite industry generate large amount of solid waste, the disposal of this waste creates environmental problems and health hazards. The study involves the experimental investigation of effect of varying proportion of granite waste powder and lime in the fly-ash in making flyash based interlocking brick and to analyses the properties of interlocking bricks such as compressive strength and water absorption. Three different types mix proportion were prepared, for first mix proportion with fly-ash with (85 to 65)\%, granite waste powder (5 to 25)\% and lime $10 \%$ were used as raw materials for production of interlocking bricks, for second mix proportion with flyash with $(73$ to 65$) \%$,granite waste powder $25 \%$ and lime (2 to 10)\% were used as raw materials, for third mix proportion with fly-ash with $60 \%$,granite waste powder $(10$ to 30$) \%$ and lime (30 to 10$) \%$ were used as raw materials, after casting the fly ash based interlocking bricks for varying different proportions, these interlocking bricks were sun dried and then tests was carried out on the interlocking bricks, for 7 and 21 days compressive strength and percentage of water absorption was determined.
\end{abstract}

Keywords - Fly ash, Granite Waste Powder, Interlocking bricks

\section{INTRODUCTION}

Bricks are most widely used as infill material in India, due to its structural strength, durability, resistance to the climatic condition, sound insulation and flexibility. Bricks are used for load bearing and non load bearing wall, partition wall, for foundations, load bearing columns and piers. for next up coming years the India could require the large quantity of building material. It has been estimated that during the period 2005-2030 in India, there will be increase in the demand for the bricks which could be approximately 500 billion bricks. The growth rate of urbanization in India was $31.3 \%$ during the period (1991-2001) and 31.8\%during (2001-2011), 217.7 million was the population of the urban during 1991, and population was 377.10 million during 2011. As there is increase in the urban population, number of cities and also towns were also been increased from 3768 to 7951 in during (1991-2001), due to growth of urbanization which lead to increase in the demand in construction sector and industrial sector.[1]

India Construction sector contributes about $10 \%$ of the GDP (gross domestic progress) with annual growth rate of $9 \%$ As construction sector is growing rapidly, the demand of construction materials is also increasing. Presently China is the largest bricks producer in Asia and India is second on the production of bricks. During 9th five year plan (1997-2002), it was estimated that US $\$ 4.5$ billion as revenues can be generated from 170 million brick (annual demand) produced. During the 11th five year plan (2007-2012) it was estimated that about US\$ 5.3 billion as generation of revenues from 220 million bricks.[2]

\subsection{Problem Statement}

Coal is the main source of energy in thermal power station, the ash is produced when the coal is burnt is been collected in the electrostatic precipitator as fly ash. fly ash basically contain toxic substances in traces, which will leads to negative impacts on the human health, plant life, environment and even on the land where fly ash will be disposed. Fly ash and Granite waste powder are industrial waste. Granite stone are shaped by cutting and polishing, during this process certain percentage of granite powder generated as waste. Granite industry generate large amount of solid and powder waste, the disposal of this waste creates environmental problems and health hazards. It is necessary to use these wastes into useful manner, attempt is made to utilise these industrial waste into alternative building brick. 1.2 Objectives of the research work

- To utilise fly-ash, granite waste powder for preparation of interlocking bricks.

- To determine the optimum mix proportion for interlocking brick. 
- To study the effect of fly-ash and granite waste powder on the properties of interlocking bricks like compressive strength and water absorption.

- To study cost analysis of interlocking bricks.

\section{LITERATURE SURVEY}

Swapnil H Patil (2016), had studied on interlocking stabilized soil bricks. Materials used were Red soil, Cement, Water, Sand and Fly ash. Method used for casting the Interlocking Soil Bricks: Manual casting \& Casting by Hydraulic Press Machines,Size of brick were $(230 \mathrm{~mm} \times 100 \mathrm{~mm} \times 100 \mathrm{~mm})$ (230mm x $150 \mathrm{~mm}$ x $100 \mathrm{~mm})$ Tests conducted were Water absorption and Compression strength on stabilized bricks. Authors conclude that if brick are prepared of ISSB bricks on site then it reduces the transportation cost and time. Maximum compressive strength for $10 \%$ cement \& soil $2.65 \mathrm{~kg}$ with compressive strength as $2.42 \mathrm{~N} / \mathrm{mm}^{2}$ and water absorption as $21.70 \%[1]$

R. K. Watile et.al (2016) had studied the use of interlocking bricks masonry has gained rapid popularity as an alternative to conventional bricks for sustainable housing. R. K. Watile et.al had carried out an experimental investigation in which the compressive strength, water absorption and density were investigated by using varying percentage of fly ash, stone dust, and sand with different mix proportion. A manmade fibre, glass fibre reinforce polymer (GFRP) utilize as reinforcing material to produce the interlocking blocks which gives appreciable results were studied. There experimental results compared with that ordinary brunt clay brick and interlocking brick found durable in aggressive environments and have sufficient strength for their use in sustainable building construction.[8]

S. Pareek. "Gainful Utilization of Marble Waste (2007) have carried the experimental work by using, laterite soil, plastic (PET) and bitumen as a raw material for the brick i.e. poly ethylene terephthalate as a plastic, size of the brick was $20 \times 10 \times 10 \mathrm{~cm}$, and weight of brick as $3 \mathrm{~kg}$, they have carried test on the index properties of the soil, and they have also carried test for bitumen, they have replaced the soil up to $80 \%$ by the plastic and bitumen by keeping the bitumen content constant $(2 \%)$, and varied the proportion of plastic content by the increment of $8 \%$, they concluded that maximum compressive strength as $7.20 \mathrm{MPa}$, water absorption as $1.824 \%$ and for second brick they have varying the bitumen content, and keeping plastic constant in soil, with bitumen up to $10 \%$, interval of $2 \%$ and $70 \%$ as optimum plastic content by the weight of the soil, [11]

R.K. Watile, S.K. Deshmukh, H.C. Muley (2014) et.al. have carried the experimental work, by using rice husk ash and clay as a raw material for the brick and the size of brick was 190x90x90 mm, with $3 \mathrm{~kg}$ weight of the brick. They have casted two different types of bricks, first brick with rice husk ash and clay as a raw material for the brick, they have added rice husk ash upto $80 \%$ with interval of $10 \%$, clay up to $40 \%$ by interval of $10 \%$ and for second brick, they have casted with rice husk ash, lime and gypsum as raw material for the brick. They have added rice hush ash upto $80 \%$ with interval of $10 \%$,lime upto $40 \%$ with interval of $10 \%$,gypsum upto $20 \%$ with interval of $10 \%$, they have found ,the maximum compressive strength and water absorption at $30 \%$ rice hush ash and $70 \%$ clay with $40 \mathrm{~kg} / \mathrm{cm} 2$ and $16.30 \%$ respectivity for the first brick. And for second brick at $50 \%$ rice husk ash, $30 \%$ lime, $20 \%$ gypsum, maximum compressive strength for 7 day as $34 \mathrm{~kg} / \mathrm{cm} 2$, for 21 day as $41 \mathrm{~kg} / \mathrm{cm} 2$ and water absorption as $17.6 \% 3.1 .1[8]$

\section{MATERIALS \& METHODOLOGY}

The materials used in preparation of interlocking were

3.1 Fly ash

3.2 Granite waste powder

3.3 Lime

\subsection{Fly Ash}

Fly ash also known as 'Pulverized fuel' is a combustion product composed of fine particles that are driven out of the boiler with the flue gases, class F flyash was used in making interlocking brick which was procured from raichur ash having Bulk density $-1.3 \mathrm{gm} / \mathrm{cc}$, Specific gravity-2.2

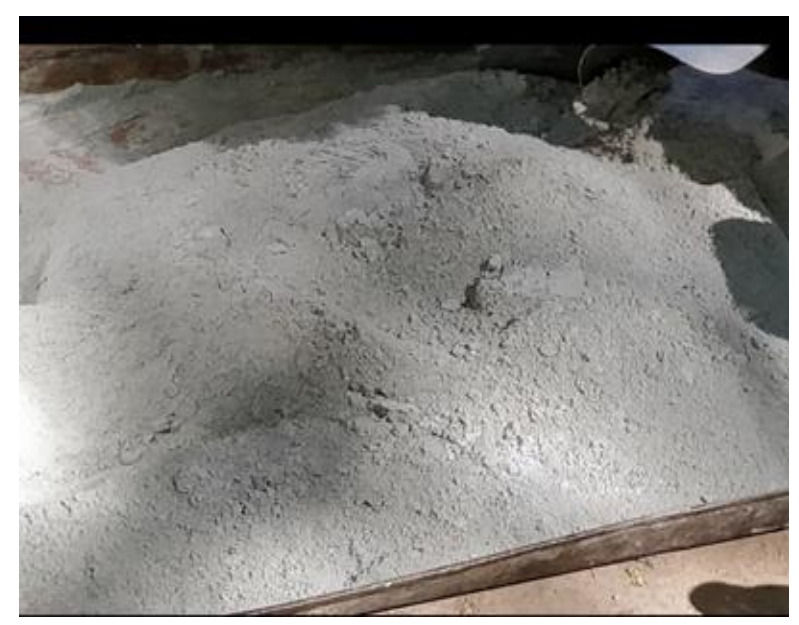

Fig.1.Fly Ash

\subsection{Granite Waste Powder}

Granite waste powder are industrial waste, procured from Ilakal quarry in Hubli, The specific gravity of Granite waste powder obtained was 2.43 physical and chemical tests were conducted on procured Granite Waste powder details are given 


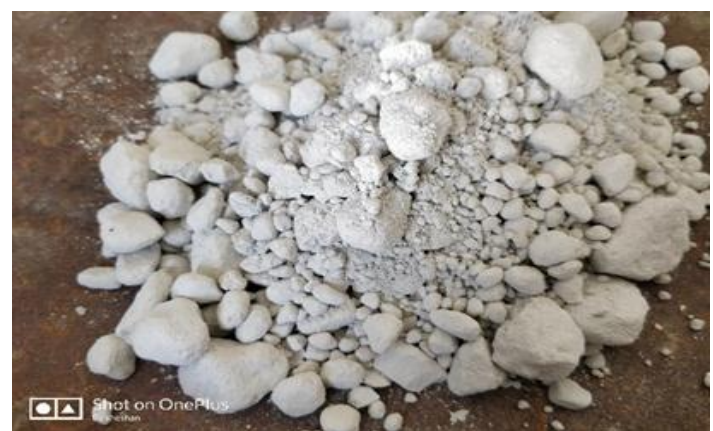

Fig. 2. Granite Waste Powder

Table 1: Chemical tests analysis of Granite Waste Powder

\begin{tabular}{|c|c|c|}
\hline Sl.No & Parameter & Observed value(\%) \\
\hline 1 & Total Ash & 90.82 \\
\hline 2 & moisture & 6.50 \\
\hline 3 & Loss of ignition & 9.18 \\
\hline 4 & $\mathrm{CaO}$ & 1.82 \\
\hline 5 & $\mathrm{MgO}$ & 0.74 \\
\hline 6 & $\mathrm{SiO}_{2}$ & 70.26 \\
\hline 7 & $\mathrm{Al}_{2} \mathrm{O}_{3}$ & 13.48 \\
\hline 8 & $\mathrm{FeO}_{3}$ & 01.04 \\
\hline
\end{tabular}

\subsection{Lime}

Locally available lime was used in making interlockingbrickhaving the specific gravity of lime is 2.32 .

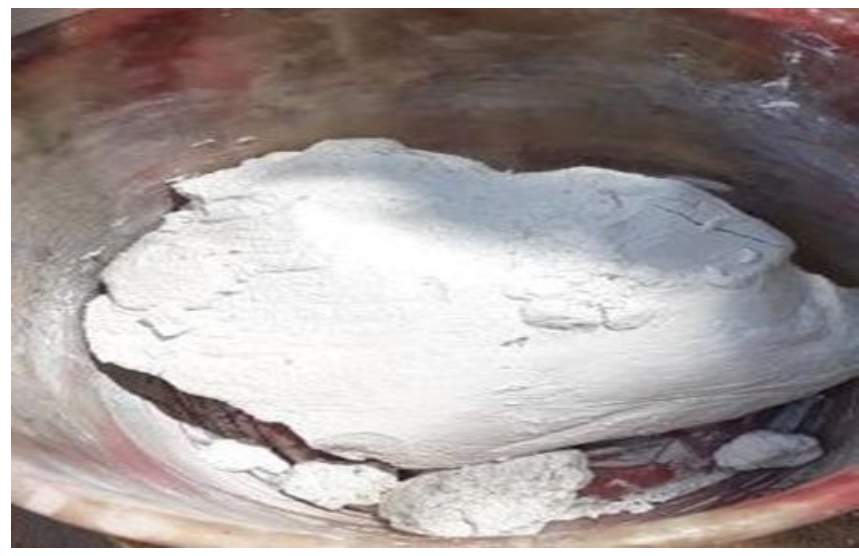

Fig. 3. Lime sample

\subsection{Methodology flow chart:}

Flow chart shown below is the sequences of methodologywhich were adopted during our research work

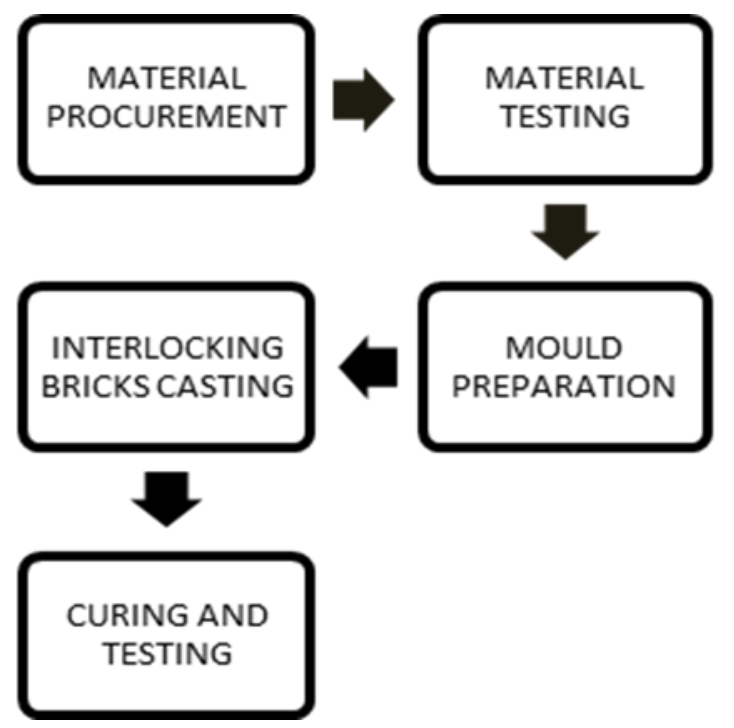

Flow chart .1.Methodology of our work

- Material were identified which are required for our research work and they were procured.

- Test on materials were done

- Wooden Mould were prepared. Interlocking bricks were casted, cured and tested for Compressive strength, Water absorption

\subsection{Mould preparation}

Wooden brick mould were used for casting of interlocking brick with the Size - $210 \mathrm{~mm}$ x $150 \mathrm{~mm}$ x $60 \mathrm{~mm}$

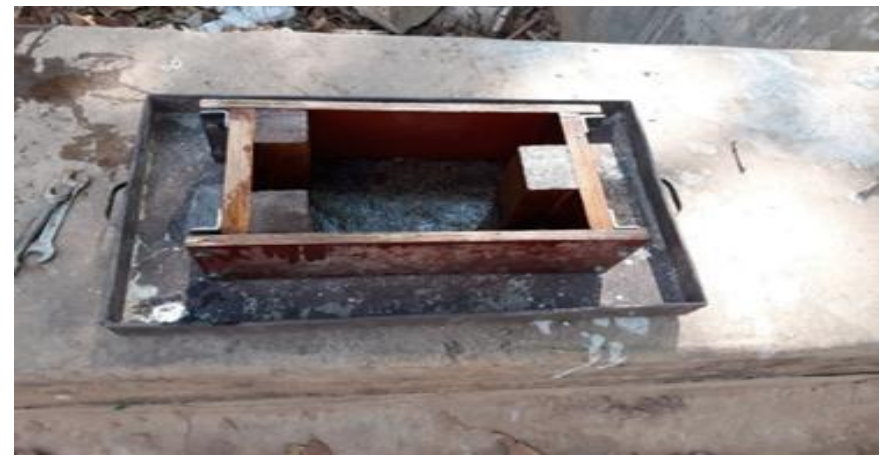

Fig. 4. Wooden Brick Mould

\subsection{Proposed mix proportion:}

Table 2,3 and 4 shows the various mix proportion used for research work 
International Journal of Engineering Applied Sciences and Technology, 2019

Vol. 4, Issue 2, ISSN No. 2455-2143, Pages 82-87

Published Online June 2019 in IJEAST (http://www.ijeast.com)

Table 2: Mix proportion 1 (Lime \% is fixed other two parameters were varied)

\begin{tabular}{|c|c|c|c|c|}
\hline $\begin{array}{l}\text { SI. } \\
\text { No }\end{array}$ & $\begin{array}{l}\text { Fly } \\
\text { ash } \\
(\%)\end{array}$ & $\begin{array}{c}\text { Granite } \\
\text { Waste } \\
\text { powder } \\
(\%)\end{array}$ & $\begin{array}{l}\text { Lime } \\
(\%)\end{array}$ & $\begin{array}{c}\text { Total No } \\
\text { Bricks } \\
\text { Casted }\end{array}$ \\
\hline 1 & 70 & 20 & 10 & \multirow{5}{*}{15} \\
\hline 2 & 72 & 18 & 10 & \\
\hline 3 & 74 & 16 & 10 & \\
\hline 4 & 76 & 14 & 10 & \\
\hline 5 & 78 & 12 & 10 & \\
\hline
\end{tabular}

Table 3: Mix proportion 2 (Fly ash \% is fixed other two parameters were varied)

\begin{tabular}{|c|c|c|c|c|}
\hline $\begin{array}{l}\text { Sl. } \\
\text { No }\end{array}$ & $\begin{array}{l}\text { Fly } \\
\text { ash } \\
(\%)\end{array}$ & $\begin{array}{c}\text { Granite } \\
\text { powder } \\
(\%)\end{array}$ & $\begin{array}{c}\text { Lime } \\
(\%)\end{array}$ & $\begin{array}{c}\text { Total } \\
\text { No } \\
\text { Bricks } \\
\text { Casted }\end{array}$ \\
\hline 1 & 72 & 24 & 4 & \multirow{5}{*}{15} \\
\hline 2 & 72 & 22 & 6 & \\
\hline 3 & 72 & 20 & 8 & \\
\hline 4 & 72 & 18 & 10 & \\
\hline 5 & 72 & 16 & 12 & \\
\hline
\end{tabular}

Table 4: Mix proportion 3 (Granite waste powder \% is fixed other two parameters were varied)

\begin{tabular}{|c|c|c|c|c|}
\hline $\begin{array}{l}\text { Sl. } \\
\text { No }\end{array}$ & $\begin{array}{l}\text { Fly } \\
\text { ash } \\
\text { (\%) }\end{array}$ & $\begin{array}{c}\text { Granite } \\
\text { Waste } \\
\text { powder } \\
(\%)\end{array}$ & $\begin{array}{l}\text { Lime } \\
\text { (\%) }\end{array}$ & $\begin{array}{c}\text { Total No } \\
\text { Bricks } \\
\text { Casted }\end{array}$ \\
\hline 1 & 70 & 18 & 12 & \multirow{5}{*}{15} \\
\hline 2 & 72 & 18 & 10 & \\
\hline 3 & 74 & 18 & 8 & \\
\hline 4 & 76 & 18 & 6 & \\
\hline 5 & $\begin{array}{l}78 \\
\end{array}$ & 18 & 4 & \\
\hline
\end{tabular}

\section{RESULTS AND DISCUSSION}

The tests conducted were:

- Compressive strength

- Water absorption

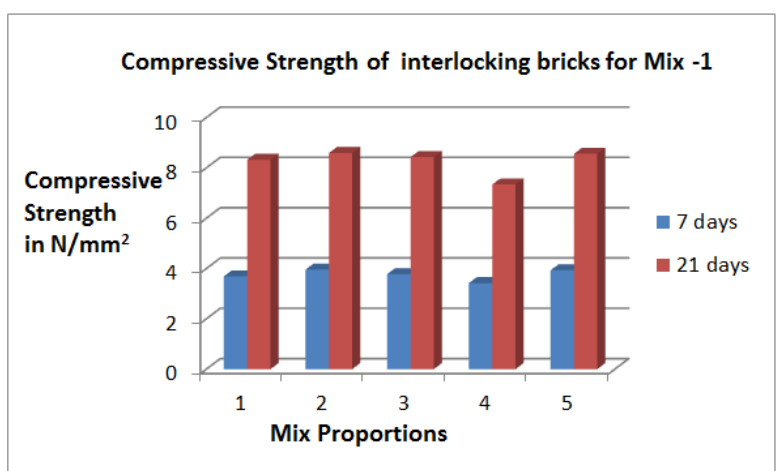

Graph 1: - Compressive strength for Mix Proportion 1

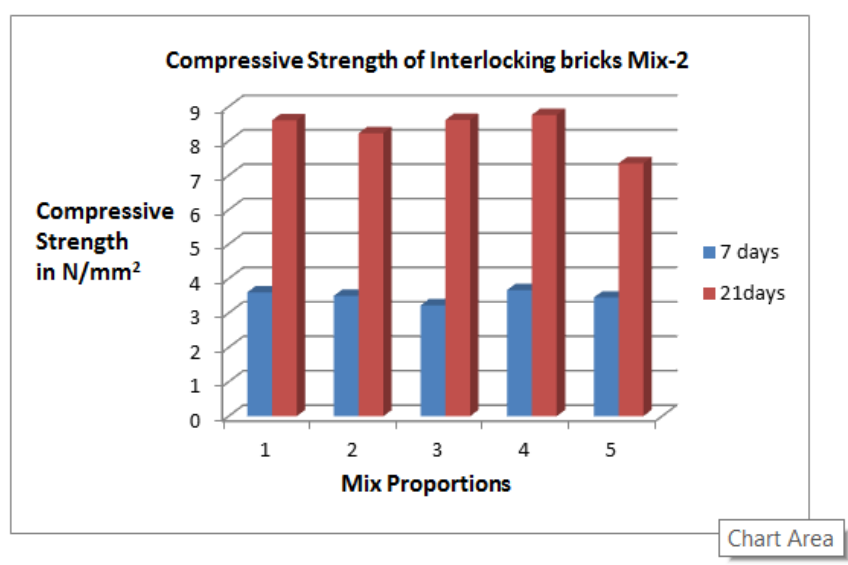

Graph 2 - Compressive strength for Mix Proportion 2

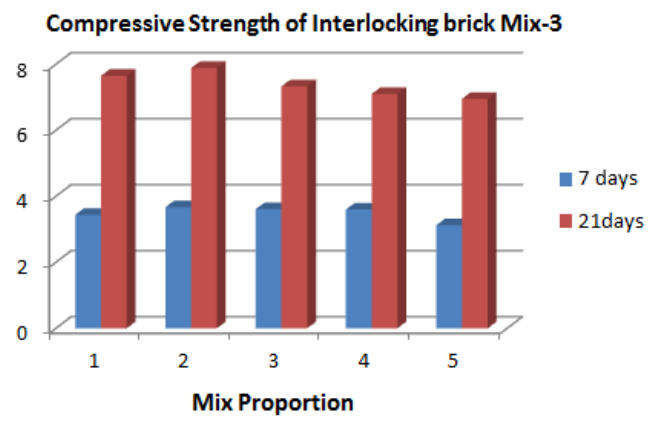

Graph 3 - Compressive strength for Mix Proportion 3

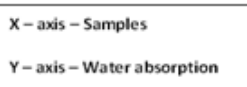

Water absorption

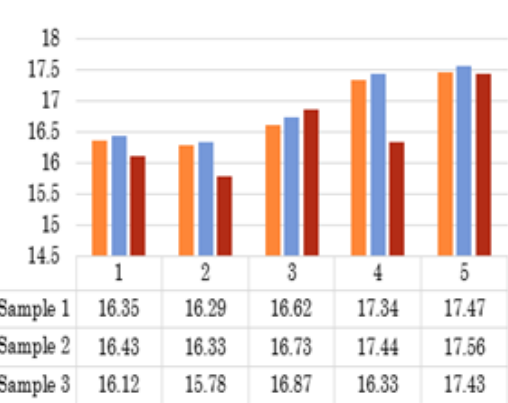

"Sample 1 "Sample 2 "Sample 3

Graph 4 - Water Absorption for optimum mix proportion 


\section{International Journal of Engineering Applied Sciences and Technology, 2019 Vol. 4, Issue 2, ISSN No. 2455-2143, Pages 82-87 \\ Published Online June 2019 in IJEAST (http://www.ijeast.com)}

\section{COST ANALYSIS}

Table 5: Cost of each interlocking is given below:

\begin{tabular}{|c|c|c|c|c|}
\hline Materials & Cost & Additional & Profit & $\begin{array}{c}\text { Cost of each } \\
\text { brick }\end{array}$ \\
\hline Lime & $\begin{array}{l}75.0 \\
\text { iunit }\end{array}$ & \multirow{3}{*}{ ₹ 0.80} & \multirow{3}{*}{1} & \\
\hline $\begin{array}{l}\text { Granite } \\
\text { powder }\end{array}$ & Free & & & ₹5.80 \\
\hline Fly Ash & Free & & & \\
\hline
\end{tabular}

The cost of each brick inclusive of all charges is $\underline{\mathbf{z 5 . 8 0}}$

For $1 \mathrm{~m}^{3}$ no of bricks - 320 units for size of $210 \mathrm{~mm} \mathrm{X} 150 \mathrm{~mm} \mathrm{X} 60 \mathrm{~mm}$ Rate per $1 \mathrm{~m}^{3}-320 \times 5.80=$ Rs $1856 /-$

\section{RESULTS}

- The optimum percentage of fly ash, granite powder and lime for Mix proportion 1, is found out to be $72 \%$ Fly ash, $18 \%$ Granite powder and $10 \%$ Lime. Compressive strength was found to be $3.96 \mathrm{~N} / \mathrm{mm}^{2}$ for 7 days and 8.59 for 21 days.

- $\quad$ The optimum percentage of fly ash, granite powder and lime for Mix proportion 2 is found out to be $72 \%$ Fly ash, $16 \%$ Granite powder and 6\% Lime. Compressive strength for this mix proportion was found out to be $3.98 \mathrm{~N} / \mathrm{mm}^{2}$ for 7 days and 8.96 for 21 days.

- The optimum percentage of fly ash, granite powder and lime for Mix proportion 3 is found out to be $72 \%$ Fly ash, $18 \%$ Granite waste powder, $10 \%$ Lime, compressive strength for this mix proportion was found out to be 3.78 $\mathrm{N} / \mathrm{mm}^{2}$ for 7 days and 8.32 for 21 days.

- The Water Absorption found out from all the 3-mix proportion was $15.20 \%, 16.10 \%, 16.50 \%$.

- Cost of each inter locking brick is $\square 5.80$

\section{CONCLUSION}

- Industrial wastes such as granite waste powder with certain percentage can be added to fly ash based interlocking brick.

- Interlocking brick require less mortar then compared with burnt brick clay.

- Faster is the construction of masonry units when we use interlocking brick then burnt clay bricks.

\section{REFERENCE}

[1] Swapnil H Patil - "Interlocking stabilized soil bricks", " Vol 2, Issue 2, 2016

[2] Abhinandan R. Gupta, Dr S.K. Deshmukh - "Interlocking brick design - paradigm for sustainable construction" Vol 3, Issue 1, Jan 2016.

[3] Amana Ocholi, Manasseh Joel - "Effect of variation in temparature on some properties of cement stabilized laterite interlocking bricks",2014
[4] Carrassco, E.V.M, Mantilla - "Compression performance of walls of interlocking brick made of iron ore by product and cement",2014

[5] Sajad Ahmed, Saddam Hussain, Mohd Awais "Behaviour of interlocking of masonry units/blocks",2012

[6] Jain A K, - "Fly Ash Utilization in Indian Cement Industry: Current Status and Future Prospects", Indian Concrete Institute, an Electronic Bulletin, Vol. 2, Issue 2, Feb.2011.

[7] Bansal Deepak - "Interlocking dry stacked masonry", 8th International Masonry Conference 2010 in Dresden.

[8] R.K. Watile, S.K. Deshmukh, H.C. Muley - "Interlocking bricks for sustainable housing development",2009

[9] M. Celik and E. Sabah, "Geological and Technical Characterisation of Iscehisar (Afyon-Turkey) Marble Deposits and the Impact of Marble Waste on Environment Pollution". Journal of Environmental Management, 87, 106-116, 2008.

[10] S. El Haggar "Sustainable Industrial Design and Waste Management: Cradle-to-Cradle for Sustainable Development" Elsevier Academic Press, 2007, Ch. 10. pp. 346-350.

[11] S. Pareek. "Gainful Utilization of Marble Waste - An Effort towards Protection of Ecology \& Environment". Centre for Development of Stones. Retrieved May 5, 2007

[12] J. Delgado, A. Va'zquez, R. Juncosa, and V. Barrientos. "Geochemical Assessment of the Contaminant Potential of Granite Fines Produced during Sawing and Related Processes Associated to the Dimension Stone Industry". Journal of Geochemical Exploration, 88, 24-27. 2006.

[13] V. Vijayalakshmi, S. Singh, and D. Bhatnagar. "Developmental Efforts in R \& D for Gainful Utilization of Marble Slurry in India" Centre for Development of Stones, 2003. Retrieved January 3, 2010

[14]P. Torres, H. Fernandes, S. Olhero, and J. Ferreira. "Incorporation of Wastes from Granite Rock Cutting and Polishing Industries to Produce Roof Tiles". Journal of the European Ceramic Society, 29, 23-30, 2009.N..

[15] Almeida, F. Branco, and J. Santos. "Recycling of Stone Slurry in Industrial Activities: Application to Concrete Mixtures". Building and Environment, 42, 810-819, 2007

[16] M. Kumar, K. Suryanarayana, and T. Venkatesh. "Value Added Products from Marble Slurry Waste". Centre for Development of Stones, 2003. Retrieved January 3, 2010 from the World Wide

[17] G. Rizzo, F. D'Agostino, and L. Ercoli. "Problems of Soil and Groundwater Pollution in the Disposal of "Marble" Slurries in NW Sicily". Environmental Geology, 55, 929935. 2008.

[18] F. Saboya, G. Xavier, and J. Alexandre. "The Use of Powder Marble By-product to Enhance the Properties of 
International Journal of Engineering Applied Sciences and Technology, 2019

Vol. 4, Issue 2, ISSN No. 2455-2143, Pages 82-87

Published Online June 2019 in IJEAST (http://www.ijeast.com)

Brick Ceramic". Construction and Building Materials, 21, 1950-1960, 2007

[19] R. K. Watile ,S. K. Deshmukh, H.C.Muley "Interlocking Brick for Sustainable Housing Development" INTERNATIONAL JOURNAL OF SCIENCE, SPIRITUALITY, BUSINESS AND TECHNOLOGY (IJSSBT), Vol. 2, No. 2, May 2014 ISSN (Print) 22777261 